\title{
EXPERIÊNCIA DE ABORDAGEM DO BIM EM DISCIPLINA NO IFPE - CAMPUS RECIFE
}

Modalidade: Experiência de ensino-aprendizagem BIM realizadas

\section{DESENVOLVIMENTO}

A disciplina de Desenho Auxiliado por computador é ofertada no $4^{\circ}$ período do curso de bacharelado em engenharia civil e, foi oferecida pela primeira vez de forma remota, contando com 20 alunos matriculados no semestre 2020.1.

0 tema foi introduzido através de aulas teóricas sobre o BIM e suas possibilidades para a construção civil. Como ferramentas didáticas, utilizaramse a plataforma Google Meet e o Google Classroom, através das quais os alunos também puderam interagir, tirar dúvidas e trazer contribuições, como forma de possibilitar uma aprendizagem ativa, com foco no aluno, como preconiza as novas Diretrizes Curriculares Nacionais (DCN's) para a engenharia.
Além disso, a disciplina contou com a colaboração de um ex-aluno da instituição, participante do projeto de pesquisa, que transmitiu para os alunos conhecimentos básicos de modelagem BIM com o uso do software Revit.

Como avaliação do conhecimento foram propostas a representação de 2 projetos, sendo o primeiro em grupo e utilizando 0 Autocad e o último, individual com o uso do Revit. Em ambos os casos, foram propostas alterações intencionais de projeto durante 0 andamento do trabalho, a fim de perceber a condução e as impressões sobre as duas situações.

Ao final de cada etapa, os alunos puderam explicitar suas opiniões sobre as atividades e a disciplina em dois questionários.

Figura 1: Possibilidades BIM

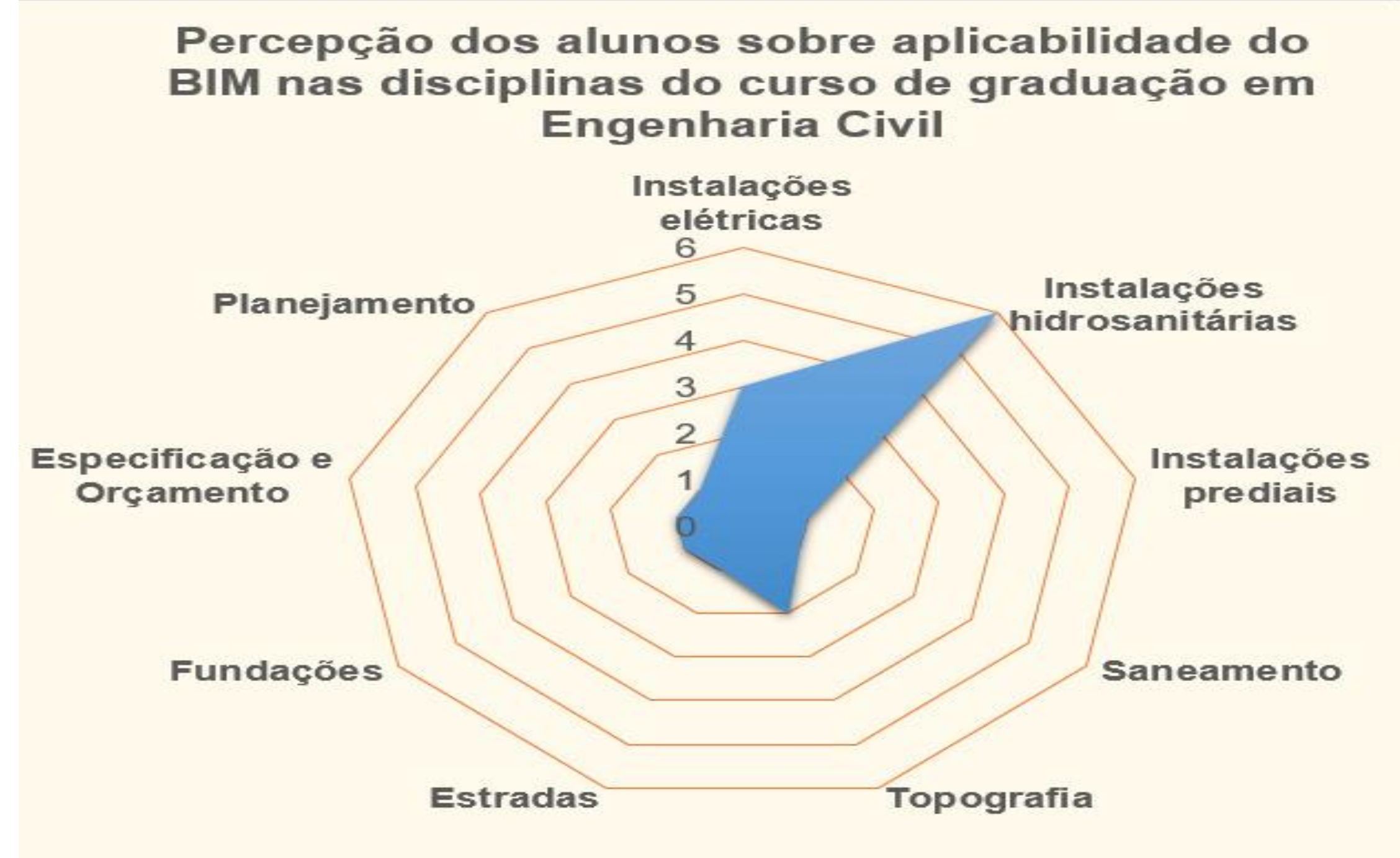

\section{LIÇÕES APRENDIDAS}

Considera-se que os resultados alcançados foram bastante promissores e que o fato de a disciplina ter sido remota não trouxe maiores complicações ou prejuízos na aprendizagem e nas oportunidades, visto que alunos e professores mantiveram contatos diários nas plataformas. Aqueles que se dedicaram durante 0 percurso conseguiram desenvolver as habilidades desejadas.
Apesar de avaliarem como altamente positiva uma inserção do BIM no curso de engenharia civil, os resultados demonstram que os alunos ainda têm visão limitada das potencialidades da metodologia.

A fig. 01 apresenta as respostas sobre as possibilidades de adoção no curso, tendo sido visualizadas, para a maioria, somente as disciplinas de instalações elétricas e hidrossanitárias.
Keylla Alves 1

Januário Leal 2

Emmanoel Neri 3

1- IFPE, keyllaalves@recife.ifpe.edu.br

2- IFPE, januarioleal@recife.ifpe.edu.br 3- IFPE, emmanoelroberto@gmail.com

\section{INTRODUÇÃO}

Essa experiência é oriunda do trabalho de projeto de pesquisa em andamento no IFPE - Campus Recife, intitulado: Estudo diagnóstico para introdução da metodologia BIM nos cursos técnicos de Edificações e Bacharelado em Engenharia. Entende-se que 0 envolvimento da comunidade acadêmica será imprescindível nesse processo. Compreender a disponibilidade de alunos, professores e gestores por uma futura introdução do BIM é fundamental. Buscouse perceber, a partir da abordagem do BIM na disciplina de Desenho Assistido por Computador, ofertada de maneira remota no semestre 2020.1, no curso de engenharia civil do IFPE - campus Recife, qual seria o grau de conhecimento atual dos alunos participantes sobre o BIM, bem como seu nível aceitação da metodologia, caso fosse implementada.

\section{AGRADECIMENTOS}

À Pró Reitoria de Pesquisa, Pósgraduação e Inovação do IFPE e à Diretoria de Pesquisa, Pósgraduação e Inovação do Campus Recife. 